\title{
39 \\ The networked (agency) regulation of competition
}

\author{
Imelda Maher
}

\section{Introduction}

The regulation of competition, as a phrase, is, at first glance, contradictory. How can we write of regulating competition when regulation and competition are classically viewed as alternatives or opposites? Competition law is concerned with deterring restraints on competition in the market mainly by prohibiting anticompetitive agreements and abuse of market dominance and by requiring prior approval of mergers that are likely to restrict competition. ${ }^{1}$ Thus, the competitive market, seen as a public good, is facilitated as the best mechanism through which to empower the consumer (Drexl 2004). Regulation, on the other hand, is classically seen as the control, order and influence of conduct through standard-setting, monitoring, compliance and enforcement (Hood et al. 2001: 23). It is closely associated with state control of the market where there is market failure and is seen as addressing particular markets-notably, utilities. It is supervisory and instrumental in nature. Competition law is generally applicable across all markets, is associated with a more rule-based doctrinal approach and is prohibitory in nature. The two phenomena are thus portrayed as opposites.

1 See, for example, the model competition law of the United Nations Conference on Trade and Development (UNCTAD 2010). 
However, this clearcut distinction obscures the extent to which regulation and competition overlap (Maher 2004). Thus, the traditional notion of regulation as command and control has dissipated in favour of more nuanced definitions where the emphasis is on 'steering' by the state rather than 'rowing'; where private and meta-regulation have decentred the state as market regulator (Coglianese and Mendelson 2010); and where competition has been introduced into classic regulatory domains-telecommunications being the best example (Baldwin et al. 1998: 24). Similarly, a shift can be seen in competition law, where a more instrumental quality has emerged, with instruments of market control appearing as part of the 'toolkit' of competition agencies. This hybridisation suggests the classic regulation/competition dichotomy needs to be more nuanced (Dunne 2014a). They can be viewed on a continuum, with command-and-control regulation at one end of the spectrum and the ordinary workings of a market based on contract law and property rights at the other end. Competition law lies somewhere in between because it constrains freedom of contract to the extent necessary to ensure competition (Maher 2004).

\section{Instruments and institutions}

Competition regimes use organisational forms and instruments that are regulatory in nature to ensure markets remain competitive. As well as the classic deterrence approach to anticompetitive behaviour with fines, injunctions and even criminal sanctions, competition regimes have developed hybrid legal instruments that straddle competition and regulation (Dunne 2014a). For example, in the United Kingdom, market studies constituting a review of a particular market may lead to a wide range of competition or regulatory actions, while sectoral studies in the European Union (EU) may lead to further individual investigations and sanctions. ${ }^{2}$ Thus, a European Commission pharmaceutical sector inquiry in 2009 led to proceedings with a fine of $€ 60$ million (AU $\$ 89$ million) imposed in one instance (Jones and Sufrin 2014: 728). ${ }^{3}$ Competition litigation may also lead to a regulatory-type outcome, for example, in disputes involving intellectual property rights (IPR). If the IPR holder's conduct is deemed anticompetitive, the outcome may be to require mandatory licensing with monitoring systems to ensure the licences

2 Enterprise Act 2002, ss. 131-4 and Regulation 1/2003 OJ 2003 L 1/1, Article 17.

3 AstraZeneca AB and AstraZeneca plc v. Commission [2012] ECR I-770, Case C-457/10P. 
are offered on a 'fair, reasonable, and non-discriminatory' (FRAND) basis. Similarly, where access to an essential facility (the classic example of which is a port) is deemed necessary to prevent anticompetitive practices, the remedy may be mandatory and very different from the traditional cease and desist (and fines) approach found in competition law (Hellström et al. 2009). A legislative variation on this can be found in Australian competition law (Dunne 2014a: 253). ${ }^{4}$

In terms of organisational form, competition regimes, like regulatory regimes, are characterised by agencies that operate at arm's length from the executive. Agency networks are an increasingly common feature of both regimes. Networks have emerged as a result of the shift from government to governance (Rhodes 1997); from 'rowing' to 'steering'; from greater delegation of executive functions to agencies; the liberalisation of markets; the exponential growth in markets as a result of globalisation; and recognition of the importance of information in securing particular policy and enforcement outcomes. Competition networks can be seen as part of this trend, especially in the transnational context where jurisdictional overlap creates incentives for communication and coordination. This overlap arises in three main contexts: between the competition agency and sectoral agencies; where there are multiple competition agencies enforcing the same rules; and internationally, given so many competition disputes are not limited to single jurisdictions but there is no international competition regime. The exponential growth in national competition regimes in the past 25 years, from 23 in 1990 to 127 in 2013, has also vastly increased the risk of jurisdictional overlap and the need for coordination of enforcement and information-sharing across borders (Capobianco et al. 2014: 21).

\section{Networks}

Börzel (1998: 260) defines networks as:

a set of relatively stable relationships which are of non-hierarchical and interdependent nature linking a variety of actors, who share common interests with regard to a policy and who exchange resources to pursue these shared interests acknowledging that co-operation is the best way to achieve common goals.

4 Competition and Consumer Act 2010, Part IIIA. 
Networks as a form of governance can be contrasted with hierarchy and markets. They may be heterogeneous or homogeneous, sites of interest mediation with a strong interdependence between the state and private actors that are largely informal and a response to the wide dispersal of resources in the modern state (Börzel 1998).

Transgovernmental networks based on discussions among government subunits, including non-executive agencies, have been a feature of supranational and international governance for over 100 years. There are three broad categories: information exchange, enforcement coordination and harmonisation (Slaughter 2004: 44, 52). Competition networks are concerned with information exchange and enforcement coordination. Harmonisation - the mandatory adoption of common international standards - is not a feature even in the EU, which is a highly integrated supranational regime. Voluntary convergence of procedural or substantive rules, which encourages commonality while allowing for national variation, is found in many competition networks (Gerber 2010: Chapter 8). For example, in the EU, the European Competition Network (ECN) developed a nonbinding model leniency program (immunity from fines for those who bring cartels that operate secretly to the attention of the competition agency) (EC 2012a). Member states committed to use their best efforts within the limits of their competence to align their programs, culminating in the adoption of 26 leniency programs out of 28 states in six years (EC 2012b). Nonetheless, competition networks are primarily information and enforcement networks, with the majority information networks where the information being exchanged is 'soft' or 'grey' information about the internal operations and the challenges faced by agencies. The most valuable information-confidential information garnered following investigation — can be exchanged only where there is a statutory base. A rare example is the ECN. ${ }^{5}$

Sokol (2011) sees all transgovernmental and transnational networks operating within a soft law paradigm - that is, measures are capable of practical effects and possibly even legal effects (Snyder 1995: 64; Ştefan 2008: 753). Consensus, peer pressure and policy learning are the preferred methods of securing change. Soft law has been preferred even where binding legal norms are available-for example, the Organisation for Economic Co-operation and Development (OECD) may enact

5 Article 12, Regulation 1/2003 OJ 2003 L 1/1. 
binding legal norms, ${ }^{6}$ but it has not done so in the competition sphere, instead relying on soft law measures, primarily recommendations. ${ }^{7}$ The United Nations Conference on Trade and Development (UNCTAD), as a subsidiary organ of the United Nations (UN), enjoys the status of an intergovernmental body and has enacted conventions in other fields, but relies on soft law measures to advance competition law in developing countries (Sokol 2011: 198). The exception is the ECN, which was set up (albeit minimally) by formal binding norms. ${ }^{8}$

Because networks operate mainly on the basis of soft law, their impact depends on political support, especially from the United States and the European Union. Braithwaite and Drahos (2000) show how the American model of competitive mega-corporate capitalism globalised and, alongside it, its commitment to competition rules. The EU emerged as a global competition law player when it rejected the Boeing/ McDonnell Douglas and General Electric/Honeywell mergers that the United States had approved and when it spearheaded (unsuccessfully) a World Trade Organization (WTO) competition regime ${ }^{9}$ (Maher 2012b). US rules are often seen as a surrogate for an international standard (Gerber 2010: 106), which may explain effective US resistance to a WTO competition regime (Freyer 2006: 154). Sokol (2011: 199) notes the powerful snowballing effect when the United States and European Union support an initiative such as the International Competition Network (ICN) and how the lack of such support is damaging, for example, for the UNCTAD model competition law (Gerber 2010: 144). China enacted a competition law in 2008 and in the future it, as well as the other 'BRICS' countries (Brazil, Russia, India and South Africa) may be regarded as equally influential in the competition sphere (Maher 2012a). For now, however, while it is a member of the Asia-Pacific Economic Cooperation (APEC) forum, China is not a member of the ICN or the OECD.

6 Convention on the Organisation for Economic Co-operation and Development, Paris, 14 December 1960, Art. 5.

7 The OECD published is first recommendation on competition policy in 1967. See: Recommendation of the Council Concerning Cooperation between Member Countries on Restrictive Business Practices Affecting International Trade, 5 October 1967, C(567) 53/final (since revised).

8 Reg. 1/2003 OJ 2003 L 1/1, Art. 11-12.

9 See Communication from the EC and its Member States, WT/WGTCP/W/152, 25 September 2000. 
The significance of political influence is most apparent in the failure of the EU initiative to include competition within the WTO and the US-supported compromise resulting in the ICN (Janow and Rill 2010). A WTO working group was set up to discuss competition law following the Uruguay Round in $1996 .{ }^{10}$ The proposal was that members would have competition laws incorporating some core principles including nondiscrimination and a ban on cartels, a voluntary code on cooperation and provision of technical assistance. The initiative failed because of the unwillingness of the United States to see a binding international regime and the concerns of developing countries that competition laws would be imposed on them, the omission of antidumping and export cartels, that technical assistance would not be forthcoming and that the main beneficiaries would be Western multinational corporations securing access to their markets (Bhattacharjea 2006). The ICN is a very loose form of enforcement cooperation, seen as necessary by the United States given the European Union's rejection of the General Electric/Honeywell merger and one that went some way to meet EU preferences for an international framework (Maher 2012a). Thus, efforts to create binding norms were jettisoned to be replaced with softer governance through networks where the emphasis is on information sharing and consensus building and where competition law is taken as a given with the emphasis on how it is enforced rather than its relationship with the state, trade or whether it is appropriate (Sum 2013). Competition networks now include those found in international bodies (OECD, UNCTAD), regional groups (APEC, the Association of Southeast Asian Nations, Nordic Cooperation, the ECN, the European Free Trade Association Network, the European Competition Association) and networks set up just for competition matters-for example, the Lusaphone Network, the Ibero-American Forum and the African Competition Network (Maher and Papadopoulos 2012). At the same time, there is exponential growth in competition regimes, which is partly voluntary, partly a response to the World Bank or International Monetary Fund (IMF) initiatives, partly arising out of regional and bilateral trade or competition agreements and partly as a result of technical assistance programs (Maher 2012b). The proliferation of networks points to coordination problems, duplication of effort, a risk of systemic incoherence and overload and a narrow managerial approach to competition enforcement that eschews wider and more controversial concerns. At the same time,

10 WTO, Ministerial Declaration, 13 December 1996, WT/MIN(96)/DEC/20, 36 ILM 218. 
the bottom-up and consensual approach allows for necessary variation in regimes and differences in approach, which may, in the long term, ensure a more responsive regulation of competition, although the extent of influence from actors such as international bodies, the European Union and the United States (and other actors depending on the network) is nonetheless an important caveat on what is understood within these networks as consensus.

Finally, these networks can be distinguished from epistemic communities, which are not defined by any particular membership, have no executive functions and are relatively amorphous but share expertise and a common discourse (Haas 1992). There is an important epistemic community of academics, bar associations and competition law practitioners in the international competition sphere (van Waarden and Drahos 2002). Such a knowledge community seeks to influence policy indirectly through its knowledge and expertise, which are acknowledged and drawn on by agencies. Given the extent to which the episteme and networks in the competition sphere overlap and are self-referential, competition law and policy may not adequately reflect wider trends in society. The episteme is also dominated by those with the greatest expertise and knowledge- that is, those from the European Union, United States and other Western states. It is not clear to what extent this expertise can be garnered to create dynamic and experimental spaces where agencies and other actors can engage to address common concerns and share best practice with a view to developing competition law in a manner widely perceived as a public good.

\section{Competition agencies and sectoral regulators}

As a significant feature of competition law practice, networks operate at different levels of enforcement and with different levels of intensity (Maher, forthcoming). Below, we explore those arising out of the interface of regulation and competition, those within states and polities where there are multiple enforcement bodies and, finally, regard is had to the largest international network, the ICN.

As a consequence of the liberalisation of sectors that historically had state monopolies or special or exclusive rights (for example, communications, energy), competition was introduced alongside regulatory mechanisms necessary to prevent market failure. The potential overlap of jurisdiction in Australia was addressed by conferring regulatory, as well as competition, powers on the competition agency in 
relation to telecommunications and energy. ${ }^{11}$ In the United Kingdom, there is concurrent jurisdiction in competition law for the competition agency, the Competition and Markets Authority (CMA), and all sectoral regulators in their respective fields (communications, gas and electricity, health services and, to a limited degree, water, rail and civil aviation) (Dunne 2014b; UK Government 2014). Only one body will apply the competition rules in any instance but a mechanism is required to decide which one. ${ }^{12}$ This is the UK Competition Network (UKCN), set up via a CMA guidance note (CMA 2014: 54). The network decides on case allocation through close cooperation. It is a forum for strategic dialogue and actively engages in peer review. It facilitates information sharing, staff training and secondment, the sharing of best practice and improved advocacy and the timely provision of information for the Annual Report on Concurrency. Hence, the 'flavour' of the network is nonhierarchical, with the guidance at pains to point out that its parameters and operations were agreed to by all its members. The CMA can remove a case from a regulator but this is seen as a remote possibility given the emphasis on close cooperation (CMA 2014: 60). The network-central to enforcement-is not mentioned in statute. Instead, its operation is set out in soft law-in an annex to the guidance note with a commitment to flexibility (CMA 2014: 1.13). Despite the shortcomings of the previous regime (only two competition cases were brought by regulators over 13 years; Whish and Bailey 2015: 465), the relatively informal and flat network model was retained under the 2013 Act but bolstered by giving substantive priority to competition law, while the minister ultimately has the power to remove competition jurisdiction entirely from a regulator, albeit following consultation. Cooperation is still seen as the best way to secure effective and appropriate enforcement of competition.

\section{Plurality of competition agencies}

Competition networks are also found in federal structures. In the United States, the two federal enforcement agencies, the Federal Trade Commission and the Department of Justice, have a clearance mechanism to decide which of them will deal with a case (US Department of Justice 2014: Chapter VII). However, jurisdiction also is partially shared with state attorneys-general, who, in addition to enforcing state antitrust

11 Australian Trade Practices Amendment (Telecommunications) Act 1997 and Competition and Consumer Act 2010, Part IIIAA.

12 The Competition Act 1998 (Concurrency) Regulations 2014, SI 2014 No. 536. 
(competition) laws, can bring actions for damages on behalf of citizens ${ }^{13}$ and seek injunctive relief for any violation of federal antitrust law. A state-to-state network of antitrust enforcement agencies emerged from the longstanding National Association of Attorneys-General in the 1980s, partly in response to a reduction in federal antitrust enforcement under the Reagan administration (Cengiz 2012: 126-40). The network facilitates multistate actions, creates opportunities for cost-sharing and cooperation in settlements and engages in policy initiatives introducing guidelines, filing amicus briefs and proposing federal bills. This informal, nonhierarchical network is a loose form of cooperation as there are constraints on information sharing and members are free to pursue their own actions. The original confrontation between the federal and state agencies that led to the creation of the network dissipated in the 1990s allowing for greater cooperation between federal and state enforcement agencies. Thus, an informal nonstatutory network was the response to a perceived crisis in enforcement and the informal cooperative structure also facilitated rehabilitation between federal and state agencies.

In China, there are three bodies responsible for the enforcement of competition law: the Ministry of Commerce is responsible for mergers, the National Development and Reform Commission has primary responsibility for pricing and the State Administration for Industry and Commerce is responsible for antimonopoly actions and other nonprice-related antitrust enforcement (Huyue Zhang 2011). An umbrella body, the Anti-Monopoly Commission, appointed by the State Council, is responsible for supervision, coordination and guidance of work under the law. ${ }^{14}$ Despite the potential for overlapping jurisdiction between the three bodies, at the moment there is no mechanism for them to coordinate their activities. However, flexibility is retained as they are not specifically mentioned in the legislation, allowing scope for jurisdictional remits to change or be amalgamated; a less drastic initiative proposed is a 'cooperation mechanism' to avoid overlap (Emch 2014), although it is not clear if such a network will emerge.

The European Union, as a supranational entity, operates in a regulatory space between a federation and a purely international body and hence the ECN is at the interface of a common single legal order and multiple regimes. Within the EU, competition law is enforced by the European Commission, an executive body responsible for application of EU law.

13 Hart-Scott-Rodino Antitrust Improvements Act 1976.

14 Antimonopoly Law 2008, Art. 9. 
Following a radical overhaul of the system at the turn of the century, competition law enforcement was (re)delegated to national competition agencies, which enforce $\mathrm{EU}$ as well as national competition laws (Maher 2010: 717). With a minimum of 29 competition agencies, there was a real concern about coordination. The response was to establish a network under legislation with the details in a nonbinding notice ${ }^{15}$ and where the rule of thumb is that if more than three jurisdictions are involved, the commission assumes jurisdiction. The European Commission remains first among equals with the ultimate power to remove a case from a national agency-thus, the shadow of hierarchy underpins the system. ${ }^{16}$ The inherent flexibility in the network has worked well (Wilks 2007). This can be explained in part by the strong commitment to confidentiality among the agencies, the fact they enforce common rules and that they can share confidential information, limited only by the extent to which it can be used for criminal actions, all within the context of a highly integrated economic union. This enforcement network, allowing for exchange of confidential information, is the most formalised competition network and yet operates mainly through informal legal structures, where, once again, the emphasis is on peer review and learning with an exceptionally high level of trust.

\section{International Competition Network}

Finally, the ICN operates in an entirely different context from the ECN. Straddling the divide between the OECD and UNCTAD, with 126 members, it is by far the largest competition network. It is the key forum for the discussion of competition issues following the collapse of the WTO initiative. With no offices, it operates virtually but for an annual meeting of members and non-governmental advisers (from academia, ${ }^{17}$ business and mainly law firms). Working groups devoted to consideration of particular topics (for example, mergers, advocacy, cartels) engage between meetings and the website is a major resource for information on best practices in enforcement, all overseen by a 15-member steering group (Maher and Papadopoulos 2012).$^{18}$ Its aim is to advocate for best practices, to develop proposals for convergence and to facilitate cooperation between agencies through policy learning. It does

15 European Commission, Notice on Cooperation within the Network of Competition Authorities [2004] OJ C101/43, Art. 11, Reg. 1/2003.

16 ibid., Art. 11(6), Reg. 1.

17 The author has been a non-governmental adviser.

18 See: internationalcompetitionnetwork.org. 
this by creating templates, toolkits and manuals and running workshops. Although it is seen as influential (Gerber 2010: 116), questions have been raised as to how it will develop following initial activity addressing "lowhanging fruit'-notably, merger notifications-while more challenging issues such as the intersection of international trade and competition and the relationship between competition law and state enterprises are largely absent (Sokol 2011: 201). It is also questionable how much convergence is either possible or desirable given the varieties of competition regimes and the contexts within which they operate (Jessop 2013).

As a transgovernmental network that is horizontal and decentred facilitating informal contact and exchange of nonconfidential information between government officials who share a common functional interest (enforcement of competition law), the ICN is currently the only acceptable forum through which the challenge of enforcement of competition laws across and within national boundaries is addressed, mainly because it operates entirely on the basis of consensus.

\section{Conclusion}

While competition law and regulation are seen as different, in recent years, the instruments and organisational nature of competition law have overlapped. The regulatory tool of the network has become a defining feature of competition law at the national and transnational levels - a trend also seen in other areas of regulation (see Holley and Shearing, Chapter 10; Drahos, Chapter 15; Tusikov, Chapter 20; and Brewer, Chapter 26, this volume). Braithwaite (2008) notes the extent to which corporations and non-governmental organisations (NGOs) have been transformed into networks, with those states which fail to adapt to this private networked governance failing to adapt to global governance. The rejection of a top-down WTO regime and the emergence of competition networks can be seen in this context as nimble responses to market dynamics. With the emphasis on information sharing, consensus and policy learning, the networks do not interrogate the values underpinning competition law but only its enforcement. This narrow functional concern, with the emphasis on expertise, knowledge and resources, allows for influence to be exerted by the best-resourced and most influential competition regimes- that is, the United States and European Union as well as other OECD states. Wider interrogation of contentious issues such as the state, the market, trade and competition 
remain sidelined for now. There is currently no prospect of more formal international competition rules, leaving networks as the main forum for engagement on competition matters. The challenge is to ensure consensus does not preclude taking full account of 'varieties of competition' where different successful narratives, cultures and experiences support competitive markets (Dowdle 2013).

\section{Further reading}

Ezrachi, A (ed.) 2012. Research Handbook on International Competition Law. Cheltenham, UK: Edward Elgar.

Lugard, P (ed.) 2011. The International Competition Network at Ten. Antwerp: Intersentia.

\section{References}

Baldwin, R, Scott, C and Hood, C (eds) 1998. A Reader on Regulation. Oxford: Oxford University Press.

Bhattacharjea, A 2006. 'The case for a multilateral agreement on competition policy: A developing country perspective', Journal of International Economics Law 9(2): 293-323. doi.org/10.1093/jiel/ jg1009.

Börzel, TA 1998. 'Organizing Babylon: On the different conceptions of policy networks', Public Administration 76: 253-73. doi. org/10.1111/1467-9299.00100.

Braithwaite, J 2008. Regulatory Capitalism: How it Works, Ideas for Making it Work Better. Cheltenham, UK: Edward Elgar. doi. org/10.4337/9781848441262.

Braithwaite,J and Drahos,P 2000. Global Business Regulation. Melbourne: Cambridge University Press.

Capobianco, A, Davies, J and Ennis, S 2014. Implication of globalisation for competition policy: The need for international cooperation in merger and cartel enforcement, Economics Department Working Papers, 20 June, OECD, Paris. Available at: ssrn.com/ abstract $=2450137$. 
Cengiz, F 2012. Antitrust Federalism in the EU and the US. Abingdon, UK: Routledge.

Coglianese, C and Mendelson, E 2010. 'Meta-regulation and self-regulation', in R Baldwin, $\mathrm{M}$ Cave and M Lodge (eds), The Oxford Handbook of Regulation. Oxford: Oxford University Press, pp. 146-68. doi.org/10.1093/oxfordhb/9780199560219.003.0008.

Competition and Markets Authority (CMA) 2014. Regulated Industries: Guidance on Concurrent Application of Competition Law to Regulated Industries. London: Competition and Markets Authority. Available at: gov.uk/government/uploads/system/uploads/attachment_data/ file/288958/CMA10_Guidance_on_concurrent_application_of_ competition_law_to_regulated_industries.pdf.

Dowdle, MW 2013. 'Whither Asia? Whither capitalism? Whither global competition law?', in MW Dowdle, J Gillespie and I Maher (eds), Asian Capitalism and the Regulation of Competition: Towards a Regulatory Geography of Global Competition Law. Cambridge: Cambridge University Press, pp. 301-25. doi.org/10.1017/ CBO9781139226349.019.

Drexl, J 2004. 'International competition policy after Cancún: Placing a Singapore issue on the WTO development agenda', World Competition 27(3): 419-57.

Dunne, N 2014a. 'Between competition law and regulation: Hybridized approaches to market control', Journal of Antitrust Enforcement 2(2): 225-69. doi.org/10.1093/jaenfo/jnu002.

Dunne, N 2014b. 'Recasting competition concurrency under the Enterprise and Regulatory Reform Act 2013', Modern Law Review 77(2): 254. doi.org/10.1111/1468-2230.12065.

Emch, A 2014. 'Chinese antitrust institutions: Many cooks in the kitchen', Competition Policy International 10(1): 217-46.

European Commission (EC) 2012a. ECN Model Leniency Programme: 2012 Revision. Brussels: European Commission. Available at: ec.europa.eu/competition/ecn/mlp_revised_2012_en.pdf. 
European Commission (EC) 2012b. 'European Competition Network refines its model leniency programme', Press release, 22 November, MEMO/12/887, European Commission, Brussels. Available at: europa.eu/rapid/press-release_MEMO-12-887_en.htm.

Freyer, TA 2006. Antitrust and Global Capitalism 1930-2004. Cambridge: Cambridge University Press. doi.org/10.1017/ CBO9780511607189.

Gerber, DJ 2010. Global Competition: Law, Markets and Globalization. Oxford: Oxford University Press. doi.org/10.1093/ acprof:oso/9780199228225.001.0001.

Gerber, DJ 2013. 'Asia and global competition law convergence', in MW Dowdle, J Gillespie and I Maher (eds), Asian Capitalism and the Regulation of Competition: Towards a Regulatory Geography of Global Competition Law. Cambridge: Cambridge University Press, pp. 3652. doi.org/10.1017/CBO9781139226349.004.

Haas, PM 1992. 'Introduction: Epistemic communities and international policy coordination', International Organization 46(1): 1-35. doi.org/10.1017/S0020818300001442.

Hellström, P, Maier-Rigaud, F and Bulst, FW 2009. 'Remedies in European antitrust law', Antitrust Law Journal 76(1): 43-63.

Hood, C, Rothstein, H and Bladwin, R 2001. The Government of Risk: Understanding Risk Regulation Regimes. Oxford: Oxford University Press. doi.org/10.1093/0199243638.001.0001.

Huyue Zhang, A 2011. 'The enforcement of the anti-monopoly law in China: An institutional design perspective', Antitrust Bulletin 56(3): 630-63.

Janow, ME and Rill,JF 2011. 'The origins of the ICN', in P Lugard (ed.), The International Competition Network at Ten. Antwerp: Intersentia, pp. 21-36. 
Jessop, B 2013. 'The complexities of competition and competitiveness: Challenges for competition law and economic governance in variegated capitalism', in MW Dowdle, J Gillespie and I Maher (eds), Asian Capitalism and the Regulation of Competition: Towards a Regulatory Geography of Global Competition Law. Cambridge: Cambridge University Press, pp. 96-120. doi.org/10.1017/ CBO9781139226349.008.

Jones, A and Sufrin, B 2014. EU Competition Law: Text, Cases and Materials. 5th edn. Oxford: Oxford University Press.doi.org/10.1093/ he/9780199660322.001.0001.

Kovacic, WE 2007. 'Lucky trip? Perspectives from a foreign advisor on competition policy, development and technical assistance', European Competition Law Journal3(3):319-28. doi.org/10.5235/ecj.v3n2.319.

Maher, I 2002. 'Competition law in the international domain: Networks as a new form of governance', Journal of Law and Society 29(1): 111-36. doi.org/10.1111/1467-6478.00213.

Maher,I 2004.'Regulating competition',in C Parker,J Braithwaite,C Scott and N Lacey (eds), Regulating Law. Oxford: Oxford University Press, pp. 187-206. doi.org/10.1093/acprof:oso/9780199264070.003.0010.

Maher, I 2010. 'Competition law modernisation: An evolutionary tale?', in P Craig and G de Búrca (eds), The Evolution of EU Law. 2nd edn. Oxford: Oxford University Press, pp. 717-41.

Maher, I 2012a. 'International competition law?', in S Muller, S Zouridas, M Frishman and L Kistemaker (eds), The Law of the Future and the Future of Law. Volume II. The Hague: Torkel Opsahl Academic EPublisher, pp. 297-308.

Maher, I 2012b. 'Transnational legal authority in competition law and governance: Commonality and networks', in G Hand1, J Zekoll and P Zumbansen (eds), Beyond Territoriality: Transnational Legal Authority in an Age of Globalisation. Leiden: Martinus Nijhoff, pp. 411-38. doi.org/10.1163/9789004227095_016.

Maher, I (forthcoming). 'Competition law networks and the challenge of transparency', in J Galloway (ed.), Intersections of Antitrust: Policy and Regulation. Oxford: Oxford University Press. 
Maher, I and Papadopoulos, A 2012. 'Competition agency networks around the world', in A Ezrachi (ed.), Research Handbook on International Competition Law. Cheltenham, UK: Edward Elgar, pp. 60-88. doi.org/10.4337/9780857934802.00011.

Papadopoulos, AS 2010. The International Dimension of EU Competition Law and Policy. Cambridge: Cambridge University Press. doi. org/10.1017/CBO9780511762147.

Rhodes, RAW 1997. Understanding Governance. Buckingham, UK: Open University Press.

Sjöblom, D and Widegren, M 2011. 'ICN membership: Opportunities and challenges for a competition authority', in P Lugard (ed.), The International Competition Network at Ten. Antwerp: Intersentia, pp. 349-56.

Slaughter, AM 2004. A New World Order. Princeton, NJ: Princeton University Press.

Snyder, F 1995. 'The effectiveness of European Community law: Institutions, processes, tools and techniques', in T Daintith (ed.), Implementing EC Law in the United Kingdom: Structures for Indirect Rule. Chichester, UK: Wiley, pp. 49-87.

Sokol, DD 2011. 'International antitrust institutions', in AT Guzman (ed.), Cooperation, Comity and Competition Policy. Oxford: Oxford University Press, pp. 187-216.

Ştefan, O 2008. 'European competition soft law in European courts: A matter of hard principles?', European Law Journal 14(6): 753-72. doi.org/10.1111/j.1468-0386.2008.00443.x.

Sum, NL 2013. 'The cultural political economy of competitiveness, competition law and competition policy in Asia', in MW Dowdle, J Gillespie and I Maher (eds), Asian Capitalism and the Regulation of Competition: Towards a Regulatory Geography of Global Competition Law. Cambridge: Cambridge University Press, pp. 79-95. doi. org/10.1017/CBO9781139226349.007. 
United Kingdom Government 2014. Contribution submitted for Item VIII of the 122nd meeting of the OECD Competition Committee on 17-18 December 2014, Roundtable on Changes in Institutional Design of Competition Authorities, OECD Doc: OECD DAF/ COMP/WD(2014)105, OECD, Paris. Available at: oecd.org/ officialdocuments/publicdisplaydocumentpdf/?cote=DAF/COMP/ WD\%282014\%29105\&doclanguage $=$ en .

United Nations Conference on Trade and Development (UNCTAD) 2010. Model Law on Competition. UN Doc: TD/RBP/CONF.7/8. Geneva: UNCTAD. Available at: unctad.org/en/Docs/tdrbpconf7d8_ en.pdf.

United States Department of Justice 2014. 'Antitrust Division relationships with other agencies and the public', in Antitrust Division Manual: Chapter VII. Washington, DC: Department of Justice. Available at: justice.gov/atr/division-manual.

van Waarden, F and Drahos, M 2002. 'Courts and (epistemic) communities in the convergence of competition policies', Journal of European Public Policy 9(6): 913-34. doi.org/10.1080/135017602 2000046427.

Whish, $\mathrm{R}$ and Bailey, $\mathrm{R}$ 2015. Competition Law. 8th edn. Oxford: Oxford University Press. doi.org/10.1093/ law:ocl/9780199660377.001.0001.

Wilks, S 2007. 'Agencies, networks, discourses and the trajectory of European competition enforcement', European Competition Journal 3(2): 437-64. doi.org/10.5235/ecj.v3n2.437. 
This text is taken from Regulatory Theory: Foundations and applications, edited by Peter Drahos, published 2017 by ANU Press, The Australian National University, Canberra, Australia. 